\title{
The Transmembrane Semaphorin Sema4D/CD100, an Inhibitor of Axonal Growth, Is Expressed on Oligodendrocytes and Upregulated after CNS Lesion
}

\author{
Caroline Moreau-Fauvarque, ${ }^{1,4}$ Atsushi Kumanogoh, ${ }^{3}$ Emeline Camand, ${ }^{1,4}$ Céline Jaillard, ${ }^{2}$ Gilles Barbin, ${ }^{2}$ \\ Isabelle Boquet, ${ }^{4}$ Christopher Love, ${ }^{5}$ E. Yvonne Jones, ${ }^{5}$ Hitoshi Kikutani, ${ }^{3}$ Catherine Lubetzki, ${ }^{2}$ Isabelle Dusart, ${ }^{1,4}$ and \\ Alain Chédotal ${ }^{1,4}$ \\ ${ }^{1}$ Institut National de la Santé et de la Recherche Médicale (INSERM) U106 and ²Biologie des Interactions Neurones/Glie INSERM U495, Institut Fédératif \\ des Neurosciences, Hôpital de la Salpêtrière, 75013 Paris, France, ${ }^{3}$ Department of Molecular Immunology, Research Institute for Microbial Diseases, Osaka \\ University, Osaka 565-0871, Japan, ${ }^{4}$ Centre National de la Recherche Scientifique Unité Mixte de Recherche 7102, Université Paris 6, 75005 Paris, France, \\ and ${ }^{5}$ Division of Structural Biology, Wellcome Trust Centre for Human Genetics, University of Oxford, Oxford OX3 7BN, United Kingdom
}

\begin{abstract}
Semaphorins are a family of secreted and membrane-bound proteins, known to regulate axonal pathfinding. Sema4D, also called CD100, was first isolated in the immune system where it is involved in B and $\mathrm{T}$ cell activation. We found that in the mouse, Sema4D is expressed in cells throughout the CNS white matter, with a peak during the myelination period. Double-labeling experiments with different markers of oligodendrocyte lineage such as olig1, olig2, platelet-derived growth factor receptor $\alpha$, and proteolipid protein showed that Sema4D was expressed selectively by oligodendrocytes and myelin. The presence of Sema4D in myelin was confirmed using Western blot. Sema4D expression in myelinating oligodendrocytes was further observed using neuron-oligodendrocyte cocultures. Moreover, using stripe assay, we found that Sema4D is strongly inhibitory for postnatal sensory and cerebellar granule cell axons. This prompted us to examine whether Sema4D expression is modified after CNS injury. At $8 \mathrm{~d}$ after spinal cord lesions, Sema4D expression was strongly upregulated in oligodendrocytes at the periphery of the lesion. Sema4D-positive cells were not colabeled with the astrocyte marker GFAP, with the microglial and macrophagic marker isolectin B4, or with NG2, a marker of oligodendrocyte precursors. This upregulation was transient because from 1 month after the lesion, Sema4D expression was back to its normal level. These results indicate that Sema4D is a novel inhibitory factor for axonal regeneration expressed in myelin.
\end{abstract}

Key words: semaphorin; oligodendrocyte; myelin; axon; spinal cord; regeneration

\section{Introduction}

In the adult CNS of mammals, lesioned axons are unable to regenerate, to a large extent because of the presence of inhibitory factors in the cellular environment of the lesioned axons (Schwab and Bartholdi, 1996). Some degree of regeneration can occur if adult axons are experimentally provided with a more permissive substrate such as peripheral nerves or embryonic tissue (Bray et al., 1987; Horner and Gage, 2000). One major breakthrough has been the demonstration that CNS myelin, which enwraps adult axons, is the major source of inhibitors for regeneration (Schwab and Bartholdi, 1996); however, for almost a decade, only two

Received July 28, 2003; revised Aug. 21, 2003; accepted Aug. 22, 2003.

This work was supported by the Institut National de la Santé et de la Recherche Médicale, the Institute for Paraplegy (IFP, Zürich), and the Christopher Reeve Paralysis Foundation to A.C. C.M-F. was supported by the IFP and the Association pour la Recherche sur le Cancer. E.Y.J. is supported by Cancer Research UK. We thank Dr. Marie Filbin for providing the anti-MAG antibody, Dr. Martin Schwab for the anti-Nogo antibody, Dr. Jane Parnes for the CD72 CDNA, and Dr. Luca Tamagnone for the plexin B1 CDNA. We thank Dr. K. T. Nguyen-Ba-Charvet for helping us with the stripe assay.

Correspondence should be addressed to Alain Chédotal, Centre National de la Recherche Scientifique Unité Mixte de Recherche 7102, Université Paris 6, 9 Quai Saint Bernard, case 12, 75005 Paris, France. E-mail: chedota@@infobiogen.fr.

Copyright $\odot 2003$ Society for Neuroscience $\quad$ 0270-6474/03/239229-11\$15.00/0 major myelin inhibitors had been identified. The first one, recognized by the IN-1 antibody (Caroni and Schwab, 1988a), was cloned as the Nogo-A protein (Chen et al., 2000; GrandPré et al., 2000; Prinjha et al., 2000). A 66 amino acid extracellular portion of Nogo-A inhibits axon outgrowth in vitro, and this requires binding to NgR, a glycosylphosphatidylinositol (GPI)-anchored receptor (Fournier et al., 2001; GrandPré et al., 2002). The myelin-associated glycoprotein (MAG) (McKerracher et al., 1994; Mukhopadhyay et al., 1994) is the second myelin inhibitor of axonal outgrowth identified in the CNS. Very recently a third myelin inhibitor, the GPI-linked oligodendrocyte-myelin glycoprotein (Omgp), has been characterized (Wang et al., 2002a). Surprisingly, MAG and Omgp have also been found to bind to $\mathrm{NgR}$ (Domeniconi et al., 2002; Wang et al., 2002a), with p75 as a co-receptor (Wang et al., 2002b), suggesting that all three myelin inhibitors share common signaling pathways (see Discussion).

It is likely, however, that additional inhibitory factors exist, and some evidence toward their existence comes from studies on developing axons. In most vertebrate species, a large number of molecules that are able to inhibit the elongation of growing axons have been identified. Most of these repulsive molecules are diffusible and belong to three families of proteins: the netrins, the 
semaphorins, and the slits (Raper, 2000; Yu and Bargmann, 2001; Wong et al., 2002). Although their function has been studied primarily in the developing nervous system, their expression is maintained in the adult CNS. These observations suggest that they might play a role in the inhibition of axonal regeneration. To date most studies have focused on the secreted semaphorins, which are expressed in fibroblasts of the glial scar in several models of CNS lesions (Pasterkamp and Verhaagen, 2001). This prompted us to investigate the possible role in the inhibition of axonal regeneration of class 4 transmembrane semaphorins, which constitute the largest semaphorin subclass (Raper, 2000). Sema4D, also called CD100, was the first transmembrane semaphorin identified in vertebrates (Hall et al., 1996). Its expression has been studied only in the embryonic brain (Furuyama et al., 1996), and it has recently been shown to induce the collapse of the growth cones of CNS axons (Swiercz et al., 2002). In this study, we show that Sema4D is expressed selectively by oligodendrocytes and myelin in the CNS and that its expression is upregulated in oligodendrocytes after adult CNS lesion.

\section{Materials and Methods Animals}

All procedures were performed in accordance to the guidelines approved by French Ministry of Agriculture, following European standards. For myelinating cultures, pregnant OF1 albino mice were used (Janvier, Le Genest Saint Isle, France). For expression study, C57BL/6 mice (Janvier) were analyzed at different postnatal (P) ages (P0, P10, P30, and adult). The day of birth was counted as P0. Transgenic plp-shble-lacZ mice (Spassky et al., 1998) were also used. Mice were anesthetized with chloral hydrate $(350 \mathrm{mg} / \mathrm{kg})$. For in situ hybridization with digoxigenin-labeled riboprobes, mice were perfused transcardially with $4 \%$ paraformaldehyde in $0.12 \mathrm{M}$ phosphate buffer, pH 7.4 (PFA). Brains were cryoprotected in $10 \%$ sucrose, frozen in isopentane $\left(-55^{\circ} \mathrm{C}\right)$, and stored at $-80^{\circ} \mathrm{C}$ until sectioning. For in situ hybridization with ${ }^{35} \mathrm{~S}$-labeled riboprobes, mice were anesthetized and decapitated, and brains were frozen immediately in isopentane and stored at $-80^{\circ} \mathrm{C}$. Serial coronal sections $\left(16\right.$ or $20 \mu \mathrm{m}$ ) were cut with a cryostat and stored at $-80^{\circ} \mathrm{C}$ before hybridization. For immunohistochemistry, mice were perfused transcardially with 4\% PFA. Brains were postfixed for $2 \mathrm{hr}$ and cryoprotected either in 30\% sucrose for sectioning with a freezing microtome or in $10 \%$ sucrose and frozen in isopentane for sectioning with a cryostat. Floating sections were stored until use at $-20^{\circ} \mathrm{C}$, in a solution of $10 \% \mathrm{H}_{2} 0,30 \%$ ethylene glycol, $30 \%$ glycerol, and 30\% phosphate buffer $0.24 \mathrm{M}, \mathrm{pH}$ 7.4.

\section{In situ hybridization}

Riboprobes synthesis. A $1.9 \mathrm{~kb}$ EcoRI-NotI fragment from a full-length mouse Sema4D cDNA (cloned in pEFBos) (Kumanogoh et al., 2000) was subcloned in pbluescriptKS + . Antisense riboprobe for $m S e m a 4 D$ was generated by linearization of this plasmid with EcoRI and subsequent incubation with T7 RNA polymerase (Roche Diagnostics, Basel, Switzerland). The olig1, olig2, and platelet-derived growth factor receptor $\alpha$ $(P D G F R \alpha)$ probes were generated as described previously (Pringle and Richardson, 1993; Lu et al., 2000). The mouse CD72 and plexin B1 cDNAs were kind gifts from Dr. Jane Parnes (Stanford University, Palo Alto, CA) (Ying et al., 1995) and Dr. Luca Tamagnone (Istituto per la Ricerca e Cura del Cancro, Torino, Italy), respectively. The in vitro transcription was performed using the Promega kit (Promega, Madison, WI), and probes were labeled with digoxigenin-UTP (Roche Diagnostics), fluorescein-UTP, or ${ }^{35} \mathrm{~S}-\mathrm{UTP}(>1000 \mathrm{Ci} / \mathrm{mmol}$; Amersham Biosciences Europe GmbH, Freiburg, Germany).

In situ hybridization with digoxigenin-labeled riboprobes. Tissue sections from postnatal mice were hybridized with digoxigenin-labeled riboprobes. Tissue sections were postfixed for $10 \mathrm{~min}$ in $4 \% \mathrm{PFA}$, washed in PBS, pH 7.4, treated with proteinase $\mathrm{K}(10 \mu \mathrm{g} / \mathrm{ml}$; Invitrogen, Carlsbad, CA) for 3-5 min, postfixed for $5 \mathrm{~min}$ in $4 \%$ PFA, washed in PBS, acetylated, and washed in PBS $1 \%$ Triton X-100. Slides were incubated for $2 \mathrm{hr}$ at room temperature in hybridization buffer (50\% formamide,
$5 \times$ SSC, $1 \times$ Denhardt's, $250 \mu \mathrm{g} / \mathrm{ml}$ yeast tRNA, and $500 \mu \mathrm{g} / \mathrm{ml}$ herring sperm, $\mathrm{pH}$ 7.4), and then tissue sections were hybridized overnight at $72^{\circ} \mathrm{C}$ with riboprobes $(0.5 \mathrm{ng} / \mu \mathrm{l})$. After hybridization, sections were rinsed for $2 \mathrm{hr}$ in $2 \times \mathrm{SSC}$ at $72^{\circ} \mathrm{C}$ and blocked in $0.1 \mathrm{M}$ Tris, $\mathrm{pH} 7.5,0.15$ $\mathrm{M} \mathrm{NaCl}$ (B1) containing 10\% normal goat serum (NGS) for $1 \mathrm{hr}$ at room temperature. After blocking, slides were incubated overnight at room temperature with anti-digoxigenin antibody conjugated with the alkaline phosphatase (1:5000; Roche Diagnostics) in B1 containing 1\% NGS. After additional washes, the alkaline phosphatase activity was detected using nitroblue tetrazolium chloride (NBT) $(337.5 \mu \mathrm{g} / \mathrm{ml})$ and 5-bromo-4-chloro-3-indolyl phosphate (BCIP) (175 $\mu \mathrm{g} / \mathrm{ml})$ (Roche Diagnostics). Sections were mounted in Mowiol (Calbiochem/Merck, Carlstadt, Germany).

Double in situ hybridization. For double in situ hybridization (ISH), the two different probes were labeled with either digoxigenin- or fluorescein-UTP. The first probe was detected with alkaline phosphatase (AP)-conjugated anti-digoxigenin antibody and developed with NBT and BCIP, which yields a purple precipitate. After the NBT/BCIP reaction, the AP-conjugated anti-digoxigenin was inactivated by incubating the sections ( $15 \mathrm{~min}$ ) in glycine, $\mathrm{pH}$ 2.2. The sections were subsequently incubated with AP-conjugated anti-fluorescein antibody and detected with 2-(4-iodophenyl)-3-(4-nitrophenyl)-5-phenyl tetrazolium chloride (Roche Diagnostics) and BCIP, which yields an orange precipitate.

In situ hybridization with ${ }^{35}$ S-labeled riboprobes. Tissue sections of P10, $\mathrm{P} 30$, and adult brains were hybridized with ${ }^{35} \mathrm{~S}$-labeled riboprobes. Sections were postfixed for 15 min in 4\% PFA, washed in PBS, acetylated, washed in PBS, dehydrated in graded ethanols, and air dried. Sections were covered with hybridization buffer containing $5.10^{5} \mathrm{cpm} / \mu$ l of riboprobes (50\% formamide, $0.3 \mathrm{M} \mathrm{NaCl}, 20 \mathrm{~mm}$ Tris- $\mathrm{HCl}, \mathrm{pH}$ 7.4, $5 \mathrm{~mm}$ EDTA, $1 \times$ Denhardt's, $10 \%$ dextran sulfate, $10 \mathrm{~mm}$ DTT, $10 \mathrm{~mm}$ $\mathrm{NaH}_{2} \mathrm{PO}_{4}, \mathrm{pH} 8$, and $250 \mu \mathrm{g} / \mathrm{ml}$ yeast tRNA, pH 7.4). Slides were hybridized overnight at $48^{\circ} \mathrm{C}$ in a humid chamber. After hybridization, sections were rinsed for $30 \mathrm{~min}$ in $5 \times$ SSC at $48^{\circ} \mathrm{C}$ and for $20 \mathrm{~min}$ in $2.5 \times$ SCC at $60^{\circ} \mathrm{C}$. Sections were then treated for $30 \mathrm{~min}$ with $20 \mathrm{mg} / \mathrm{ml} \mathrm{RNase} \mathrm{A}$ at $37^{\circ} \mathrm{C}$, washed in $2 \times$ SSC and in $0.1 \times$ SSC for $15 \mathrm{~min}$ each, dehydrated, and air dried. Autoradiograms were obtained by apposition of the sections to Hyperfilms ( $\beta \max$, Amersham) for $3 \mathrm{~d}$. For histological analyses, the slides were dipped in photographic emulsion (NTB2, Kodak Integra Biosciences, Cergy le Haut, France) and exposed for $\sim 12 \mathrm{~d}$. Then, slides were developed at $14^{\circ} \mathrm{C}$ in D19 (Kodak, Rochester, NY), fixed in AL4 (Kodak), and subsequently rinsed, dehydrated, and mounted with $\mathrm{Cy}-$ toseal 60 (Stephens Scientific, Riverdale, NJ). Slides were analyzed in bright- and dark-fields with a Zeiss Axiophot microscope (Zeiss, Germany).

\section{Immunohistochemistry}

For Sema4D immunostaining, $40 \mu \mathrm{m}$ coronal sections were cut on a freezing microtome. Free-floating sections were rinsed in $0.075 \%$ Triton X-100 (Sigma, St. Louis, MO) in PBS (PBS-T), blocked for $1 \mathrm{hr}$ at room temperature (RT) in PBS containing $0.2 \%$ gelatin (Prolabo, Fontenaysous-Bois, France) and $0.25 \%$ Triton X-100 (PBS-G-T), and then incubated overnight at RT with a rat monoclonal antibody against Sema4D (BMA-12) (Kumanogoh et al., 2000). This antibody is a hybridoma supernatant, used at 1:10 dilution in PBS-G-T. Sections were washed in PBS and then incubated for $2 \mathrm{hr}$ at RT with anti-rat IgG [Cyanine 3 (Сy3) conjugated, developed in goat, 1:200; Chemicon International, Temecula, CA]. Double immunostaining against Sema4D and $\beta$-galactosidase was performed on cryostat brain sections (20 $\mu \mathrm{m}$ thick) from P10 to P13 plp-shble-lacZ mice. Detection of Sema4D was performed as described above. Detection of $\beta$-galactosidase was performed with a rabbit anti- $\beta$-galactosidase antibody (1:1000; Cappel, ICN Pharmaceuticals, Costa Mesa, CA) followed by an FITC-conjugated sheep anti-rabbit IgG antibody (1:200; Eurobio, Les Ulis, France). For proteolipid protein (PLP) immunostaining after in situ hybridization for Sema4D, we first performed the standard in situ hybridization, but proteinase $\mathrm{K}$ digestion $(10 \mu \mathrm{g} / \mathrm{ml})$ was shortened to $2 \mathrm{~min}$. After in situ hybridization with a Sema4D riboprobe, sections were rinsed in PBS-T, blocked for $1 \mathrm{hr}$ at RT in PBS-G-T and incubated overnight at RT with a rat monoclonal antibody against PLP (clone AA3) (Yamamura et al., 
1991). This antibody is a hybridoma supernatant, used at 1:10 in dilution PBS-G-T. Sections were then incubated in a biotinylated rabbit anti-rat antibody (1:200; Dako, Glostrup, Denmark) and an HRP-conjugated streptavidin (1:400; Amersham). The sections were developed with a diaminobenzidine reaction.

\section{Sema4D expression construct}

The soluble recombinant fragment of SEMA4D (sSEMA4D) construct was designed to encode an extracellular region of sema4D (residues 1-657 of the mature protein) followed by a lysine residue and a C-terminal histidine tag for purification. A fragment of the SEMA4D gene was produced by PCR amplification, using as a template a cDNA clone containing 2061 bp of the SEMA4D gene kindly provided by Neil Barclay (William Dunn School of Pathology). The forward primer ( $5^{\prime}-$ CTCTATCTAGAAGCCCCT) included 23 bases of the upstream region of the SEMA4D start codon and an $\mathrm{XbaI}$ restriction endonuclease site. The reverse primer (5'-GGAATTCTGATCAATGATGATGATGATGATGCTTCGTGGATGCCACCAAC) was designed to add a lysine residue and six histidines before a stop codon as well as incorporating $B c l \mathrm{I}$ and EcoRI restriction endonuclease sites for cloning. The amplified product was subcloned into the glutamine synthase-encoding expression vector pEE14 using $\mathrm{XbaI}$ and $\mathrm{BclI}$ restriction sites to produce pCL11. The fidelity of the SEMA4D gene sequence was confirmed by dideoxy sequencing.

\section{Expression and purification}

The pCL11 construct was transfected into Lec3.2.8.1 Chinese hamster ovary cells using Pfx-8 lipids (Invitrogen). Clones resistant to $15 \mu \mathrm{M}$ methionine sulfoximine were selected, and several of these expressed sSEMA4D at levels of 3-4 mg/l. For large scale production of sSEMA4D, the clones were grown in roller bottles to confluence before switching to media containing $2 \%$ fetal calf serum (FCS) and supplemented with 2 $\mathrm{mm} \mathrm{Na}$ butyrate. Recombinant secreted sSEMA4D was purified from conditioned media to homogeneity using metal-ion affinity chromatography (Ni-NTA Agarose; Qiagen) followed by gel filtration chromatography (Superdex S200 HR10/30, Amersham Biosciences). The elution profile of soluble concentrated sSEMA4D from the Superdex 200 column gave a major peak at a position that was constant with the molecule being a dimer. The protein was judged to be $>95 \%$ pure on the basis of visual inspection of a Coomassie-stained SDS-polyacrylamide gel after electrophoresis.

\section{Myelinating cultures}

Cultures were performed as described (Demerens et al., 1996; Charles et al., 2000) either on poly-L-lysine-coated $14 \mathrm{~mm}$ glass coverslips (OSI, Maurepas, France) or directly on poly-L-lysine-coated 24-well plastic plates. Briefly, forebrains were removed from 15-d-old mouse fetuses and dissociated mechanically and by enzymatic digestion with $0.025 \%$ trypsin (Biological Industries, Kibbutz Beit Haemek, Israel) for $15 \mathrm{~min}$ at $37^{\circ} \mathrm{C}$. After washing, the pellet was passed gently through a nylon mesh $(63 \mu \mathrm{m})$ and then resuspended in DMEM (Seromed, Noisy le Grand, France) containing 10\% FCS (Eurobio, Les Ulis, France). A total of 5.10 ${ }^{4}$ cells per well were plated and seeded in DMEM containing 10\% FCS to facilitate attachment for $30 \mathrm{~min}$, and then $500 \mu$ l of culture medium was added to each well. Standard culture medium consisted of B-S medium (Bottenstein et al., 1979) supplemented with $0.5 \%$ FCS and $1 \%$ penicillin-streptomycin (Biological Industries).

Cultures were fixed with $4 \%$ PFA at room temperature for $10 \mathrm{~min}$, rinsed, and then saturated in DMEM containing 50\% sheep serum for 20 min. Anti-Sema4D antibody (1:10) was diluted in PBS containing $0.5 \%$ Triton X-100 and, after washing, incubated for $30 \mathrm{~min}$ at RT in anti-rat Alexa-conjugated secondary antibodies (1:1000; Molecular Probes). For double staining, the first step was incubation with the anti-Sema4D antibody followed by incubation in the secondary antibody. Cultures were fixed with $4 \%$ PFA at room temperature and then incubated with antimyelin basic protein (MBP) (1:200; Clinisciences), anti-myelin oligodendrocyte glycoprotein (MOG) (1:10) (Brehm et al., 1999), or monoclonal antibody (mAb) A2B5 (mouse IgM; American Type Culture Collection, Rockville, MD) antibody, followed by the corresponding secondary antibody.

\section{Isolation of myelin and Western blot}

Myelin was prepared from freshly dissected 3-week-old OF1 mouse brain according to the method of Norton and Poduslo (1973) with minor modifications. Briefly, 10 brains were homogenized in $170 \mathrm{ml}$ of $0.85 \mathrm{M}$ sucrose in $10 \mathrm{~mm}$ Tris buffer, $\mathrm{pH}$ 7.4, containing $2 \mathrm{~mm}$ EDTA and $1 \mathrm{~mm}$ PMSF. The homogenate was centrifuged overnight in a SW 28 Beckman rotor at 22,500 rpm. The crude myelin at the $0.25 / 0.85 \mathrm{M}$ interface was collected and osmotically shocked with $10 \mathrm{vol}$ of distilled water. The myelin was washed with Tris EDTA buffer and collected by centrifugation; the pellet was kept at $-80^{\circ} \mathrm{C}$ until SDS-PAGE analysis. Purified myelin was run on 8 or $10 \%$ acrylamide gels. Approximately $50 \mu \mathrm{g}$ of purified myelin was loaded in each well. Proteins were transferred on Hybond + membrane (Amersham) and incubated with anti-MAG monoclonal antibody (1:1000; a kind gift from Dr. M. Filbin, City University of New York), anti-CD100 (1:500; Transduction Laboratories, Lexington, KY). or anti-Nogo-A (a kind gift from Dr. M. Schwab, University of Zurich, Zurich, Switzerland), followed by anti-mouse HRP or anti-rabbit HRP (1:5000; Dako).

\section{Stripe assay}

Stripe assay was performed as described in Nguyen-Ba-Charvet et al. (2001). A mix of purified Sema4D ectodomain $(500 \mu \mathrm{g} / \mathrm{ml})$ and fibronectin or laminin $(10 \mu \mathrm{g} / \mathrm{ml}$; Sigma) in PBS was injected into the matrix channels and incubated for $2 \mathrm{hr}$ at $37^{\circ} \mathrm{C}$, and then a blocking solution of fluorescein-conjugated BSA (2\% in PBS; Molecular Probes) was injected into the channels and incubated for $2 \mathrm{hr}$ at $37^{\circ} \mathrm{C}$. Next, the channels were rinsed four times by injecting PBS, after which the coverslip was removed and rinsed in water. The coverslip was then coated with laminin at $1.5 \mu \mathrm{g} / \mathrm{ml}$ for granule cells and $5 \mu \mathrm{g} / \mathrm{ml}$ for dorsal root ganglia (DRG) and incubated for $2 \mathrm{hr}$ at $37^{\circ} \mathrm{C}$. Coverslips were rinsed in water and placed in the appropriate culture medium. The cerebellum of P5 mice was dissected, and granule cells were purified using a Percoll gradient following standard procedures (Gao and Hatten, 1994). Cells $(1.5 \times$ $10^{7}$ ) were aggregated overnight in a Labtek tissue chamber at $37^{\circ} \mathrm{C}$ in granule cell medium (Gao and Hatten, 1994). Approximately 10 spheres were plated on each stripe and cultured for $24-36 \mathrm{hr}$ in granule cell medium. DRG from P6 mice were dissected and incubated in collagenase (1.6 mg/ml; Sigma), DNase 1 ( $16 \mu \mathrm{g} / \mathrm{ml}$; Worthington) in nutrient mixture F12 (Invitrogen) for $1 \mathrm{hr}$ at $37^{\circ} \mathrm{C}$. DRG were split into two fragments, plated on the stripe (approximately five DRG per stripe), and cultured for $36 \mathrm{hr}$ as described previously (Nguyen-Ba-Charvet et al., 2001). Explants were fixed in $4 \%$ paraformaldehyde, $0.33 \mathrm{~m}$ sucrose and labeled with anti- $\beta$-tubulin.

\section{Spinal cord lesions}

Female Swiss mice (weighing $20 \mathrm{gm}$ at the time of lesion; Janvier) were used. Mice were anesthetized with ketamin $(146 \mathrm{mg} / \mathrm{kg})$ and xylazin $(7.4$ $\mathrm{mg} / \mathrm{kg}$ ). After the lesion, the animals were returned to their cages and given ad libitum access to food and water. The procedure used to perform spinal cord lesions has been adapted from one described previously in rats (Dusart and Schwab, 1994). Briefly, a longitudinal cut was made along the midline to lower thoracic level. The dorsal one-half to twothirds of the cord was bilaterally transected by cutting transversely with iridectomy scissors, and skin was then sutured. At each time point $(8 \mathrm{~d}$ and 1 month after the lesion), three animals were anesthetized and perfused transcardially with 4\% PFA for immunohistochemistry. For controls, three nonoperated animals were processed in the same way. Spinal cords were removed, postfixed for $2 \mathrm{hr}$, and cryoprotected in $30 \%$ sucrose. The spinal cords were cut in the sagittal plane $(24-\mu \mathrm{m}$-thick freefloating sections) on a freezing microtome. The sections were incubated overnight in the antibody against Sema4D (BMA12, 1:10) and in a polyclonal antibody against GFAP (1:3000; Dako) or a rabbit anti-NG2 polyclonal antibody (1:500; Chemicon) or in FITC-conjugated isolectin B4 (Griffonia simplicifolia; 1:50; Sigma). The sections were then incubated for $2 \mathrm{hr}$ in an anti-rat IgG (Cy3 conjugated, developed in goat, 1:200; Chemicon International) and in an anti-rabbit IgG (FITC conjugated; $1: 200)$. 


\section{Results}

Sema4D mRNA is expressed in myelinating oligodendrocytes

As described previously (Furuyama et al., 1996), in mouse embryos Sema4D mRNA was expressed at a high level in many neurons throughout the CNS (data not shown). At birth, however, Sema4D mRNA expression was rapidly downregulated and could be detected only in a small number of cells scattered in the forebrain, cerebellum, and brainstem (Fig. 1A). From P0 to P10, the number of cells expressing Sema4D mRNA increased progressively, and they were found in all of the CNS; however, labeled cells were concentrated in the white matter at the level of all major fiber tracts, from the olfactory bulb and the corpus callosum in the forebrain to the spinal cord (Fig. $1 B, C$ ). This expression pattern suggests that Sema4D mRNA is expressed by oligodendrocytes, which are the myelin-forming cells in the CNS and are known to start proliferating around birth (Spassky et al., 2001). Several genes expressed at different stages of oligodendrocyte development have been identified previously (for review, see Spassky et al., 2001). To confirm that Sema4D was expressed in developing oligodendrocytes, we performed double in situ hybridization for Sema4D and other genes such as PDGFR $\alpha$ (Pringle and Richardson, 1993) and the basic-helix-loop-helix transcription factors Olig1 and Olig2 (Lu et al., 2000). We performed this analysis on forebrain and cerebellum sections from P10P13 animals, which display a high level of Sema4D expression. We found that $95 \%$ of the Sema4D-expressing cells also expressed Olig2 or Olig1 mRNAs (Fig. 1E,F) and that the number of Sema4Dexpressing cells represented $\sim 20 \%$ of the population of Olig2-expressing cells. In contrast no more than $5 \%$ of the Sema4D oligodendrocytes coexpressed PDGFR $\alpha$ (Fig. $1 D$ ), which is mainly expressed at early stages of oligodendrocyte development (Spassky et al., 2001). Moreover, in embryos we could not detect Sema4D mRNA in regions where oligodendrocyte progenitor cells are generated, such as the ventral spinal cord on either side of the central canal or the anterior entopeduncular region in the basal forebrain (Spassky et al., 1998; Olivier et al., 2001; data not shown). These observations suggest that Sema4D is expressed in a subpopulation of oligodendrocytes at the time when they start colonizing the prospective white matter tracts to form myelin.

To further confirm this result we combined in situ hybridization for Sema4D with immunocytochemistry for the PLP. Although the transcript for $p l p / d m-20$ has been shown to be expressed very early during embryonic development (Timsit et al., 1992, 1995) in oligodendrocyte progenitors (Spassky et al., 1998), the corresponding PLP protein has been shown to be detectable
Po
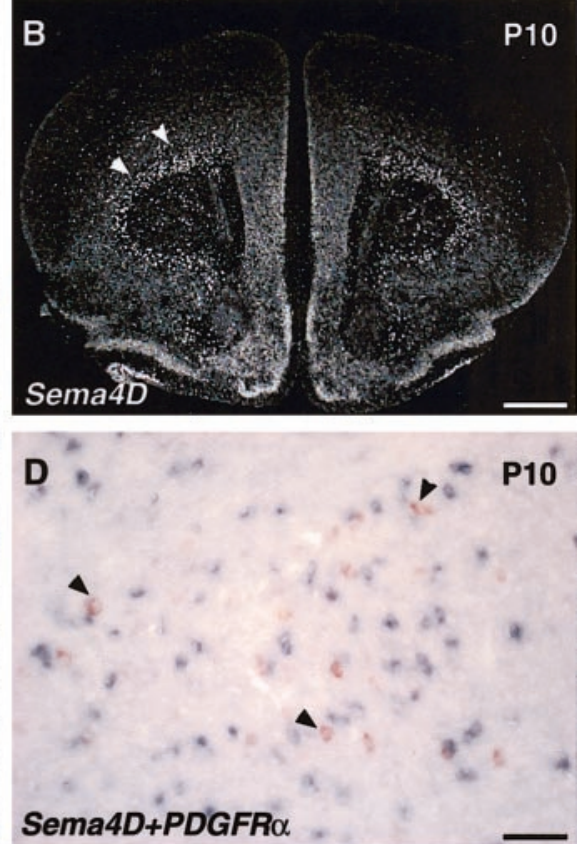

\section{Sema4D+PDGFR $\alpha$}

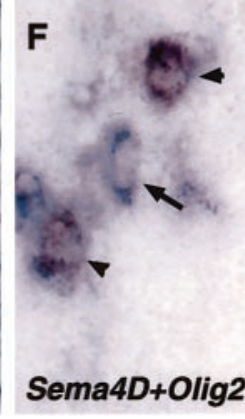

Figure 1. Expression of Sema4D mRNA in oligodendrocytes of the postnatal mouse brain. In situ hybridization was performed ( $F$, respectively. $A, A t P 0$, Sema4D expression in the brainstem is restricted to few dispersed cells in the gray matte ( ( $E$ ) (blue) and Olig2 ( $F$ ) (blue) shows that Sema4D-expressing cells represent a subset of Olig1-or Olig2-expressing cells. Examples of double-labeled cells are indicated by arrowheads, and single olig1-or olig2-labeled cells are indicated by arrows. Scale bars: $A$, $400 \mu \mathrm{m} ; \mathrm{B}, 900 \mu \mathrm{m} ; C, 120 \mu \mathrm{m} ; D, E, 60 \mu \mathrm{m} ; F, 20 \mu \mathrm{m}$.

with the AA3 mAb only in myelinating oligodendrocytes (Perez Villegas et al., 1999). In agreement with the results of the double in situ hybridization, we found that $95 \%$ of the Sema4Dexpressing oligodendrocytes coexpressed PLP (Fig. 2A). In addition, we did not detect Sema4D mRNA in GFAPimmunopositive astrocytes (data not shown). Sema4D mRNA was still detected in oligodendrocytes in the white matter of the adult CNS, but their number is lower than in 1-month-old animals (data not shown).

\section{Oligodendrocytes express the Sema4D protein in vivo and in vitro}

We next tried to determine whether oligodendrocytes also expressed the Sema4D protein using a previously characterized anti-Sema4D monoclonal antibody (Kumanogoh et al., 2000). From birth until P10, Sema4D-immunoreactive cells were detected throughout the CNS in a pattern identical to Sema4D 

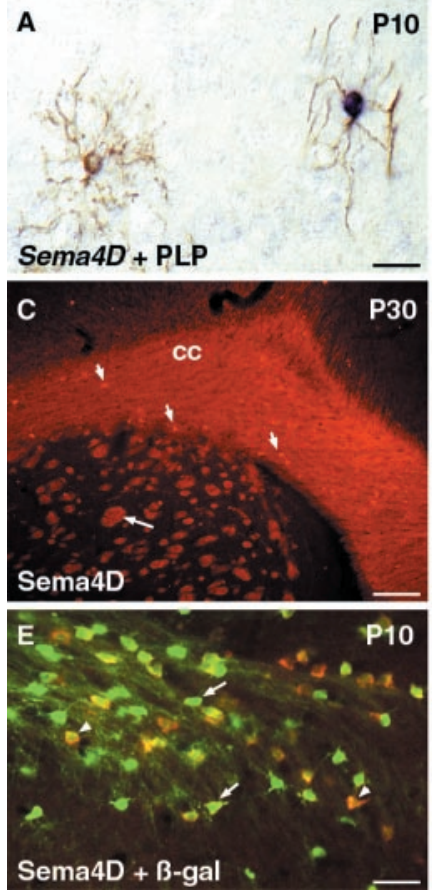

P10
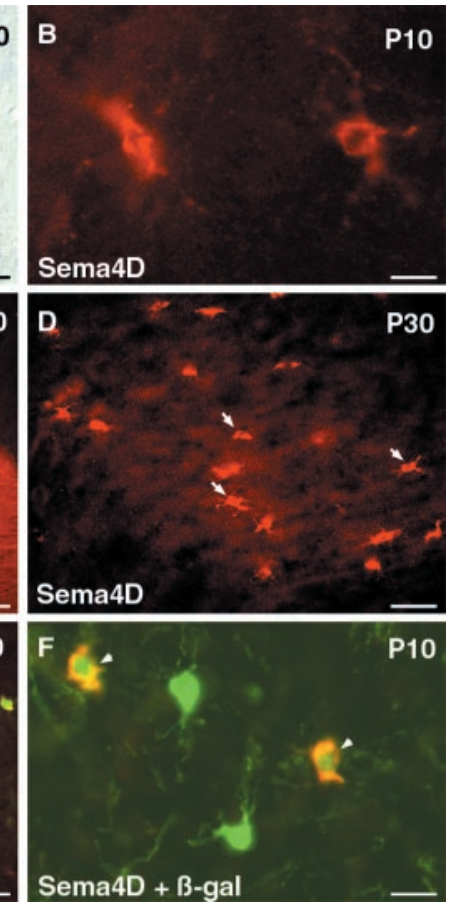

Figure 2. Expression of Sema4D mRNA and Sema4D protein in mouse oligodendrocytes. $A$, At P10, PLP antibody immunostaining (brown) combined with in situ hybridization for Sema4D (blue) shows that a subpopulation of oligodendrocytes expressing PLP coexpress Sema4D. B, At P10, Sema4D antibody labels in the CNS white matter, cells that have the morphology of oligodendrocytes. C, D, At P30, myelin in the corpus callosum (Cc) and in the striatum (long arrow) is strongly labeled by Sema $4 D$ antibody. Dispersed oligodendrocytes labeled by anti-Sema $4 D$ are also observed in the corpus callosum (C, D, short arrows). E, In P10, PLPlacZ brain, Sema4Dexpressing cells (red) represent a subpopulation of $\beta$-galactosidase ( $\beta$-gal)-positive (green) oligodendrocytes. Double-labeled cells are indicated by arrowheads, and single $\beta$-galactosidase-positive cells are indicated by arrows. $F$, Higher magnification shows examples of double-labeled cells (arrowheads). Scale bars: $A, B, F, 20 \mu \mathrm{m} ; C, 140 \mu \mathrm{m} ; D, E, 35 \mu \mathrm{m}$.

mRNA (Fig. 2). At P10 the morphology of Sema4D-expressing cells was very similar to PLP-expressing cells, suggesting that they were oligodendrocytes (Fig. $2 B$ ). Sema4D expression progressively increased to peak at P30 (Fig. 2C). At this age, the Sema4D antibody intensely labeled dispersed cells in the white matter (Fig. $2 C, D$ ) but also all myelinated tracts (white matter) in a pattern similar to the MBP (data not shown). This suggests that Sema4D is localized not only on the cell body of oligodendrocytes but also on myelin (see Fig. 4E). We further confirmed that Sema4Dimmunoreactive cells were oligodendrocytes using plp-shble-lac $Z$ transgenic mice (Spassky et al., 1998). In this line, the PLP promoter drives expression of $\beta$-galactosidase in all oligodendrocytes (we could not directly combine PLP and Sema4D immunostaining because both antibodies are generated in rat). We found that at P10-P13, virtually all Sema4D-expressing cells ( 97\%) also expressed $\beta$-galactosidase, with Sema4D-expressing cells representing $\sim 30 \%$ of the $\beta$-galactosidase cells (Fig. $2 E, F$ ). Overall these results demonstrate that in the postnatal mouse brain Sema4D is expressed in only a subpopulation of oligodendrocytes. Last, Sema4D was not detected in Schwann cells (data not shown).

The expression of Sema4D by oligodendrocytes was further studied and assessed using myelinating neurons-oligodendrocytes cocultures derived from E15 mouse forebrain. During the first week, a weak staining was detected in some A2B5-positive cells (Fig. $3 A, B$ ). Because A2B5 mAb is known to label neurons, it is likely that these Sema4D+/A2B5+ cells correspond to neurons
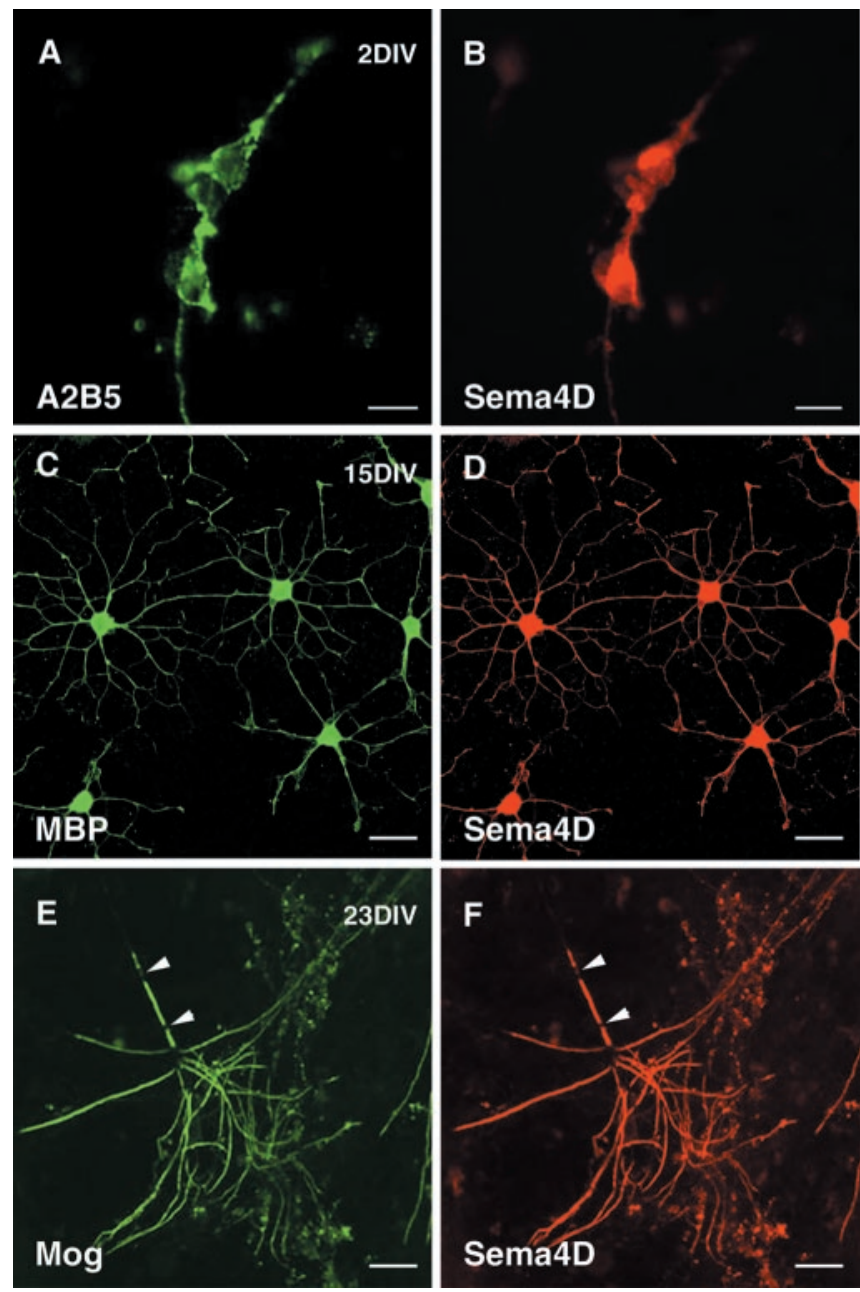

Figure 3. Sema4D expression in myelinating cultures. Neurons-oligodendrocytes myelinating cocultures were derived from E15 mouse cerebral hemispheres and stained at $2(A, B), 15$ $(C, D)$, or $23(E, F)$ DIV with anti-Sema $4 D$ antibody $(B, D, F)$ and $A 2 B 5(A)$, anti-MBP $(C)$, or anti-MOG ( $E$ ) mAbs. $A, B$, At 2 DIV, Sema4D was detected on cells labeled with the A2B5 mAb. These cells could be either neurons or oligodendrocyte precursor cells. C, D, At 15 DIV, mature nonmyelin-forming oligodendrocytes identified by their expression of MBP $(C)$ also expressed Sema4D.E, F, Under our culture conditions, myelin began to be deposited around axons at 18-21 DIV. Sema4D was strongly expressed on myelinated internodes, co-labeled by anti-MOG mAb.

as described previously (Furuyama et al., 1996). Later, the number of Sema4D-expressing cells increased, and at $15 \mathrm{~d}$ in vitro (DIV) all MBP-positive mature oligodendrocytes were expressing Sema4D (Fig. 3C,D). This staining was maintained in MOGpositive cells, either nonmyelinating or myelinating. At 20-25 DIV, when oligodendrocytes begin to deposit myelin around axons (Lubetzki et al., 1993), Sema4D expression was still very high in myelin-forming oligodendrocytes. Oligodendrocyte processes and myelinated internodes were labeled, but Sema4D was not detected on the cell bodies. At that stage, Sema4D immunolabeling was identical to the one observed using MOG antibodies (Fig. $3 E, F)$. At no time were GFAP- or $\beta$-tubulin-positive cells seen as Sema4D positive (data not shown). This confirmed that expression of Sema4D protein is restricted to oligodendrocytes.

The presence of Sema4D in myelin was finally confirmed by Western blot analysis (Fig. 4E). Using an anti-Sema4D-specific antibody, a band at $\sim 150 \mathrm{kDa}$ was clearly observed in myelin extracts from P21 mouse brain (Fig. $4 E$ ) as described previously in the immune system (Kumanogoh et al., 2000). Nogo-A and MAG, two other myelin inhibitors of axonal regeneration, were 

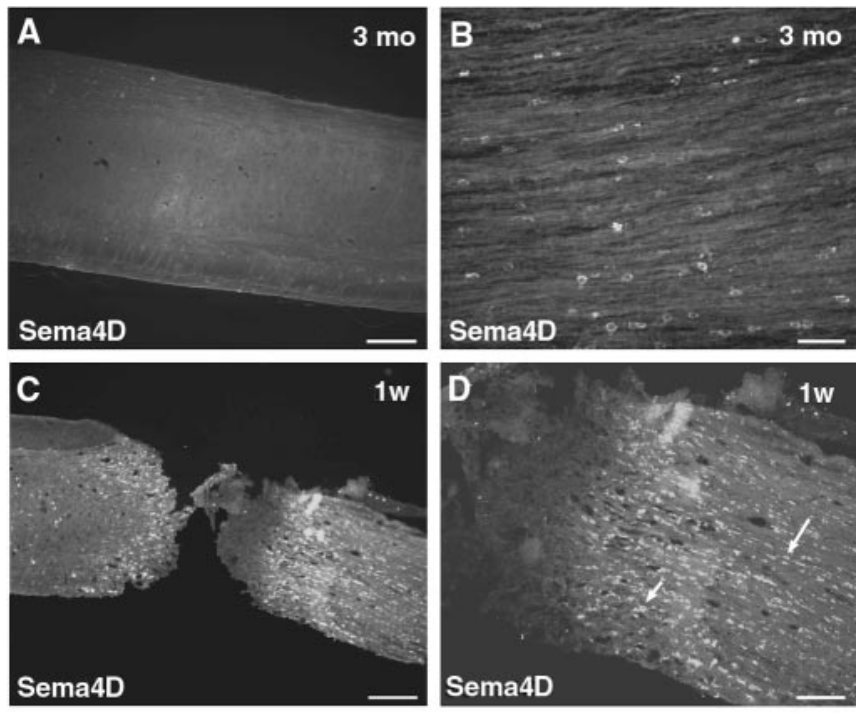

E

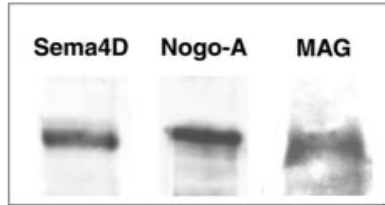

Figure 4. Sema4D expression in the adult spinal cord is upregulated after CNS injury. Control $(A, B)$ or lesioned $(C-F)$ parasagittal sections of spinal cord were immunostained with Sema4D antibody $(A-D) . A, B$, In the adult spinal cord of adult control mice, a weak expression of Sema4D is observed in some oligodendrocytes in the white matter and on myelin. C, D, One week (1w) after spinal cord injury, a strong upregulation of Sema $4 D$ expression is observed in the vicinity of the lesion that appears as a dark area. The number of cells expressing Sema4D ( $D$ arrows) near the lesion is increased compared with intact regions. $E$, Immunoblot analysis of Sema4D expression in myelin extracts. Myelin proteins from 3-week-old mice were analyzed with antisera to Sema4D, Nogo-A, or MAG. As described previously, a band at $150 \mathrm{kDa}$ was detected with anti-Sema4D, a band at $220 \mathrm{kDa}$ for Nogo $\mathrm{A}$, and a band $\sim 100 \mathrm{kDa}$ for MAG. Scale bars: $A, C, 200 \mu \mathrm{m} ; B, 50 \mu \mathrm{m} ; D, 100 \mu \mathrm{m}$.

also detected in the same extracts (Fig. $4 E$ ); however, the Western blot cannot be used to compare the relative abundance of the inhibitors, because the affinity of the antibodies used may be very different.

\section{Sema4D expression in oligodendrocytes is transiently upregulated after spinal cord lesion}

Sema4D has recently been shown to be a strong collapsing factor for the growth cones of several populations of CNS axons (Swiercz et al., 2002). In addition, it induces retraction of PC12 cell neurites (Perrot et al., 2002) and inhibits the spreading of 3T3 cells (data not shown). These results, together with our present data showing that in the postnatal CNS Sema4D is expressed by oligodendrocytes, suggested that Sema4D could be one of the myelin proteins involved in the inhibition of axonal regeneration. This prompted us to determine whether Sema4D expression is modified after CNS injury.

Sema4D immunoreactivity was studied at various times, 8 and $30 \mathrm{~d}$, after thoracic spinal cord hemisection. As described above, in the intact spinal cord, Sema4D was expressed in few oligodendrocytes in the white matter tracts (Fig. 4A,B). One week after the lesion, two wide bands of intensely Sema4D-immunoreactive oligodendrocytes were observed in the white matter areas immediately surrounding the lesion that appears as a dark area (Fig. 4C). Each band extended on both sides of the cut (proximal and distal)
(Fig. 4C). Sema4D-positive cells were aligned along fiber tracts and presented the same morphology as Sema4D oligodendrocytes in the intact spinal cord (Fig. 4D). Sema4D-positive cells were constantly observed at the periphery of the lesion (Fig. $4 C, D)$; however, the density of Sema4D-positive cells was much higher than in intact spinal cord (Fig. 4, compare $B, D$ ). To confirm that these cells were differentiated oligodendrocytes, we performed double staining of spinal cord lesions with Sema4D and several markers of glial and microglial cells. At the periphery of the lesion, we observed strong GFAP-immunoreactive astrocytes (Fig. 5A). Double immunohistochemistry for anti-GFAP-antiSema4D showed that the region of Sema4D upregulation was overlapping with the one of high GFAP expression (Fig. 5A-C); however, no double-labeled cells (GFAP positive and Sema4D positive) could be observed, confirming that Sema4D is not expressed by astrocytes. Macrophages and activated microglial cells at the lesion can be revealed using the isolectin B4 (Streit and Kreutzberg, 1987). Likewise, the chondroitin sulfate proteoglycan NG2 is a good marker of oligodendrocyte precursors cells (Jones et al., 2002). The double staining for anti-NG2-antiSema4D and for isolectinB4-anti-Sema4D showed that the regions in which Sema4D upregulation was observed only partially overlapped with the regions containing NG2 and isolectin B4positive cells (Fig. 5D-F, G-I). Indeed, these latter extended to the center of the lesion and were not restricted to the periphery (Fig. 5D, G). NG2- or isolectin B4-positive cells were smaller than the ones overexpressing Sema4D. Furthermore, no doublelabeled cells (isolectin B4 positive and Sema4D or NG2 positive and Sema4D positive) could be observed (Fig. 5F,I) Thus, these results indicate that Sema4D-positive cells were not macrophages, activated microglial cells, or oligodendrocyte precursors. It is therefore most likely that they are oligodendrocytes. This upregulation of Sema4D expression in oligodendrocytes was transient because from 1 month after the lesion Sema4D expression was back to its normal level (data not shown).

\section{Sema4D is inhibitory for postnatal CNS axons}

So far, Sema4D has only been shown to induce the collapse of embryonic axons (Swiercz et al., 2002). To further support a possible involvement of Sema4D in the inhibition of axonal regeneration, we tried to determine whether Sema4D is inhibitory for more mature axons, in particular from DRG and cerebellar granule cells. We used affinity-purified Sema4D extracellular domain (see Materials and Methods). When the protein was added directly to the culture medium of P5-P6 DRG or granule cell dissociated neurons or explants, the number of collapsed growth cones after $1 \mathrm{hr}$ was not significantly different from control (data not shown); however, because Sema4D is a transmembrane protein enriched in myelin (Fig. $4 E$ ), it is more likely to act on growth cones as an immobilized substrate than in solution. Thus, we decided to examine whether Sema4D is able to repel mature DRG and granule cell axons in the so-called "stripe" assay (Walter et al., 1987) in which the axons grow parallel to alternating stripes of two different proteins or protein combinations, making it possible to test the axons' preference for one over the other. When confronted with alternating lanes of laminin only, DRG and granule cell axons grew randomly, regardless of the lanes (Fig. $6 A, C)(n=72$ and 6 , respectively). In contrast, when given a choice between laminin and Sema4D, both DRG axons ( 19 of 23 explants; three experiments) and granule cell axons (99 of 108 explants; three experiments) avoided the Sema4D-containing lanes (Fig. 6B,D). This demonstrates that Sema4D is inhibitory for mature axons. 

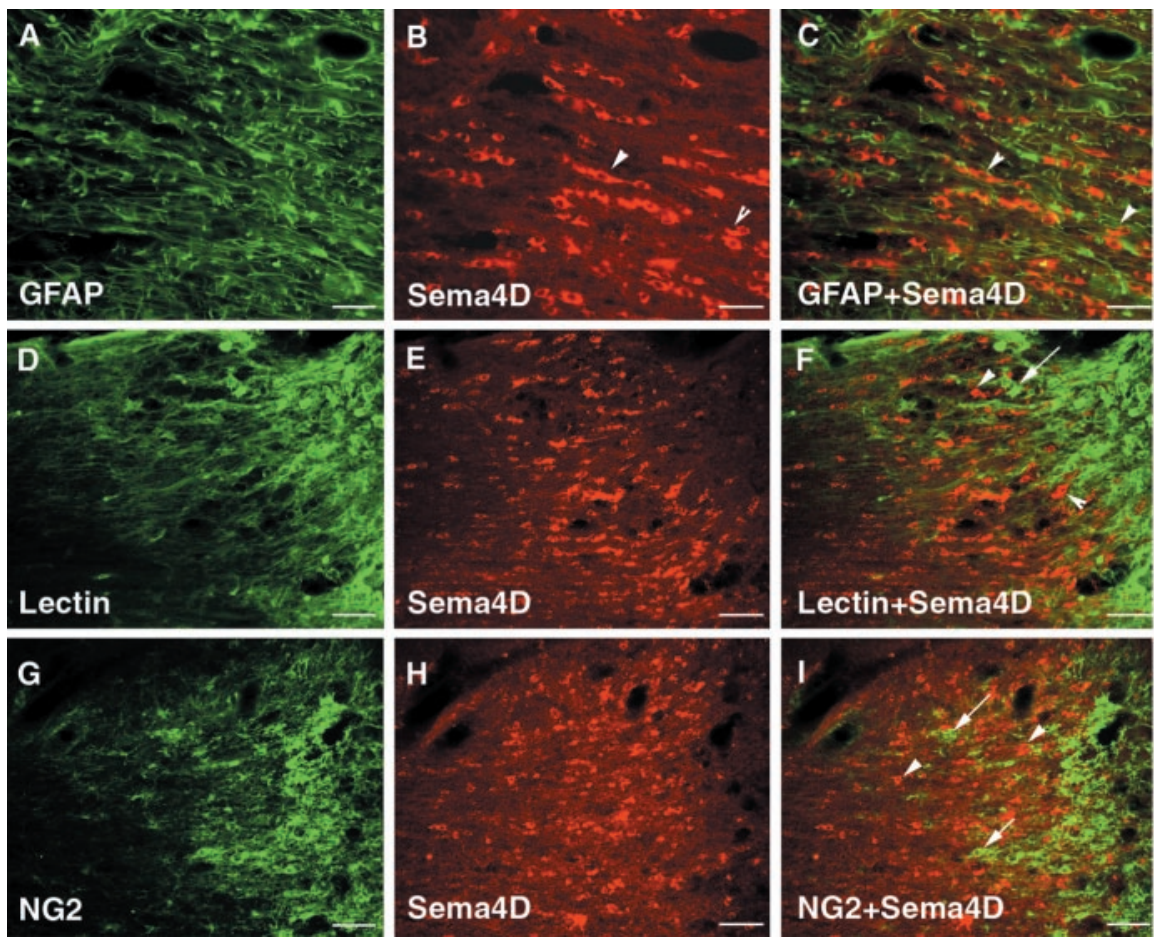

Figure 5. Characterization of Sema4D-expressing cells after adult spinal cord injury. Parasagittal sections of spinal cord 1 week after lesion were immunostained with $\operatorname{Sema} 4 D(B, C, E, F, H, I), \operatorname{GFAP}(A, C)$, and NG2 $(G, I)$ antibodies or isolectin $B 4(D, F)$. $A, A f t e r$ spinal cord injury, the glial scar contains a dense network of hypertrophic GFAP-immunostained processes oriented perpendicularly to the cut. B, Sema4D expression is upregulated in cells (arrowheads) present around the lesion site and oriented in a paralle direction to the astrocytic processes. C, Double labeling with GFAP (FITC) and Sema4D (Cy3) antibodies shows that these Sema4Dpositive cells (arrowheads) are not astrocytes. D, F, FITC-conjugated isolectin B4 reveals the presence of macrophages or activated microglial cells, or both, in a 1-week-old lesion. The cells are round ( $F$, arrow) or ramified according to their state of activation. $E$, $F$, Double labeling with isolectin B4 (FITC) and Sema4D (Cy3) shows that Sema4D-expressing cells ( $F$, arrowheads) are not macrophages or activated microglial cells $(F$, arrow). $G$, One week after injury, many NG2-positive oligodendrocyte precursors accumulate at the lesion. $H$, I, Double labeling with NG2 (FITC) and Sema4D (Cy3) antibodies indicates that Sema4D-positive cells (I, arrowheads) are not oligodendrocyte precursors (I, arrows). Scale bars: $A-C, 40 \mu \mathrm{m} ; D-I, 80 \mu \mathrm{m}$.

\section{Expression of Sema4D receptors in the CNS}

Sema4D has two known receptors: plexin B1 (Tamagnone et al., 1999) and CD72, a transmembrane protein belonging to the C-type lectin family whose expression in the CNS is unknown (Kumanogoh and Kikutani, 2001). To start characterizing the receptor mediating Sema4D function in the CNS, we studied the expression of its known receptors by in situ hybridization. From E11 to birth, plexin B1 mRNAs were detected only in proliferating cells in the ventricular zone from the spinal cord to the olfactory bulb (Fig. $7 A, B$ ) (and data not shown). From birth, plexin B1 was also clearly expressed in the subventricular zone lining the telencephalic ventricles (Fig. 7C), and this expression was maintained in the adult brain (Fig. 7D). From P10, plexin B1 was also expressed in Purkinje cells in the cerebellum (Fig. 7D) (and data not shown). Plexin B1 mRNA was not expressed in other postmitotic neurons. We next studied CD72 expression. Although CD72 mRNA was not detected in the CNS of mouse embryos (data not shown), it was highly expressed in the postnatal and adult CNS. Interestingly, CD72 expression was very broad and detectable in virtually all neurons (Fig. $7 E-G$ ). A high level of expression was detected in the hippocampus and neocortex (Fig. $7 E, F)$ and in cerebellar granule cells (Fig. $7 G$ ). No signal was observed with a sense probe (data not shown). These data suggest that CD72 but not plexin B1 could mediate Sema4D inhibitory activity on postnatal axons.

\section{Discussion}

\section{Sema4D is a semaphorin expressed} on oligodendrocytes

The semaphorins are one of the largest families of axon guidance molecules with more than 20 members identified in vertebrates (Raper, 2000). Multiple studies using semaphorin-specific probes have shown that in mammals they are widely expressed in the nervous system and also in many organs outside the CNS. Surprisingly, in the intact CNS, semaphorin expression has been detected only in neuronal cells (Skaliora et al., 1998; Raper, 2000), although Schwann cells which form myelin in the PNS express the secreted semaphorin Sema3B (Püschel et al., 1996). Thus, the expression pattern of the class 4 semaphorin, Sema4D/CD100, is unique because it is selectively expressed in the postnatal mouse brain by oligodendrocytes with a peak during the period of myelin formation. In the embryonic mouse brain, however, Sema4D is widely expressed throughout the CNS in many postmitotic neurons but not detectable in regions in which oligodendrocyte progenitors are generated (Furuyama et al., 1996; present study; A. Chédotal and C. Moreau-Fauvarque, unpublished data). This suggests that Sema4D expression is very tightly regulated during development.

Sema4D was originally identified in the immune system using monoclonal antibodies (Herold et al., 1995). Sema4D is a $150 \mathrm{kDa}$ homodimeric transmembrane protein expressed on the majority of hematopoietic cells, including B and T lymphocytes and monocytes (Delaire et al., 1998). Sema4D is involved in T cell activation (Herold et al., 1995) and also induces B lymphocytes to aggregate and improves their viability in vitro. In addition, Sema4D enhances antibody production in vivo, as well as B cell responses in vitro (Kumanogoh et al., 2000, 2001). Sema4D can therefore function as a ligand in the immune system (Kumanogoh et al., 2001); however, Sema4D cytoplasmic domain can associate with the transmembrane tyrosine phosphatase CD45 and unidentified intracellular proteins with Ser-Thr kinase activity (Delaire et al., 1998). The cytoplasmic domain of Sema4D also contains consensus sites for tyrosine and serine phosphorylation (Delaire et al., 1998). This suggests that Sema4D could also function as a receptor. Although Sema4D is the first semaphorin detected on oligodendrocytes, these cells have been shown to express neuropilin-1, a ligand-binding subunit of the receptor complex for secreted class 3 semaphorins. Interestingly, Sema3A can induce the retraction of oligodendrocyte processes (Ricard et al., 2001). Moreover, some secreted semaphorins can orient in vitro the migration of oligodendrocyte precursors (Sugimoto et al., 2001; Spassky et al., 2002). Several semaphorins, including Sema4D, have been detected in oligodendrocyte cultures by RT-PCR (Cohen et al., 2003). Our results strengthen the idea that semaphorins and their receptors play important roles in oligodendrocyte biology. Sema4D expression peaks during the my- 

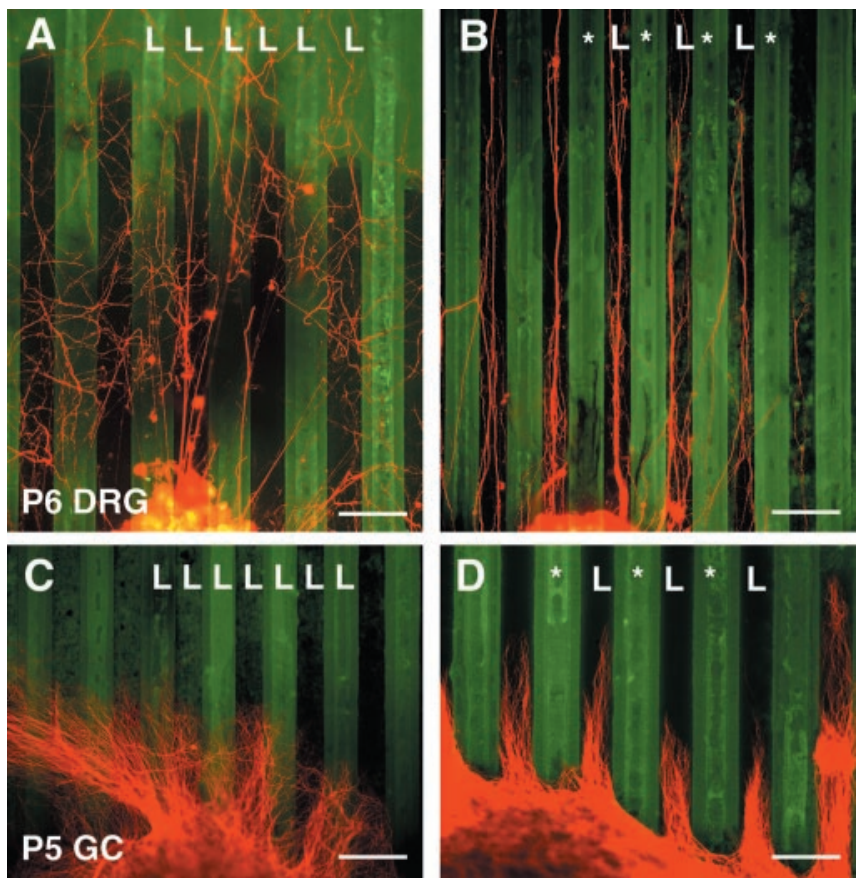

Figure 6. DRG and granule cell axons avoid Sema4D. P6 DRG $(A, B)$ or P5 granule cell $(C, D)$ explants were cultured on substrates patterned with alternating stripes of Sema $4 D$ (asterisk) or laminin (L). Explants were immunolabeled for class III $\beta$-tubulin, and the Sema4D stripes were labeled with fluorescein-conjugated BSA. A, B, DRG and cerebellar axons grow homogeneously when confronted with laminin only $(A, C)$, whereas when given a choice between Sema $4 D$ and laminin, they strongly avoid Sema4D $(B, D)$. Scale bars, $60 \mu \mathrm{m}$.

elination period, suggesting that Sema4D could participate in this process. In addition, Sema4D could be involved in some oligodendrocyte-related pathologies such as multiple sclerosis. Sema4D knock-out mice that have been obtained recently show severe impairments of B cell development, T cell priming, and immune response (Shi et al., 2000). Interestingly, Sema4D -/mice are resistant to experimental autoimmune encephalomyelitis (Kumanogoh et al., 2002b), a result that could be explained in part by the absence of Sema4D on the oligodendrocytes of the mutant.

\section{Sema4D is a novel myelin inhibitor of axonal growth}

It is well established that inhibitory factors present in the environment of lesioned axons play a major role in restraining axonal regeneration in the adult mammalian CNS (for review, see Fawcett and Asher, 1999). Many of these molecules are poor or nonpermissive substrates for elongating axons. This is the case for many components of the extracellular matrix, such as chondroitin sulfate proteoglycans (CS-PGs) (Moon et al., 2001). They are expressed in the glial scar that forms after a CNS lesion, but a few, such as NG2 and versican, are also expressed by oligodendrocytes (McTigue et al., 2001; Asher et al., 2002). Infusion of the enzyme chondroitinase $\mathrm{ABC}$, which denudes the core proteins of the CS-PG of their GAG chains, promotes regeneration of nigrostriatal axons (Moon et al., 2001) and spinal cord axons (Bradbury et al., 2002). Likewise, class 3 semaphorins have all been detected in the core of the scar tissue (Pasterkamp et al., 1999; De Winter et al., 2002). For instance, Sema3A expression in the glial scar is detectable 1 week after axotomy and persists for at least up to 2 months after injury (Pasterkamp et al., 1999). Furthermore, the expression level of Sema3A mRNA is modified in lesioned neurons after peripheral nerve crush, or bulbectomy (Pas- terkamp et al., 1998a,b; Williams-Hogarth et al., 2000). These results suggest that semaphorins might play a role in the inhibition of axonal regeneration (Pasterkamp et al., 1998b; Gavazzi, 2001).

Myelin inhibitors of axonal regeneration seem to be particularly involved during the early phase that follows the injury, before the glial scar forms (Caroni and Schwab, 1988b; Schwab and Bartholdi, 1996), as clearly demonstrated by the improved regeneration in myelin-immunized mice (Huang et al., 1999). Although secreted semaphorins are not expressed by oligodendrocytes, Sema4D fulfills all of the required criteria for a myelin inhibitor. First, we show in this study that in the developing brain of rodents, this semaphorin is expressed by oligodendrocytes when they start to form myelin but is not detectable on Schwann cells or immature oligodendrocytes that are not inhibitory for CNS axons (Schwab and Caroni, 1988). Second, Sema4D is repellent for mature DRG and granule cell axons in the stripe assay, and conditioned medium containing soluble Sema4D can induce the collapse of embryonic CNS growth cones in vitro (Swiercz et al., 2002) and the retraction of PC12 cell neurites (Perrot et al., 2002) and inhibit the spreading of 3 T3 cells (our unpublished data). Third, Sema4D expression is strongly and transiently upregulated in oligodendrocytes that surround the lesion site, which has never been shown for other myelin inhibitors such as Nogo (Huber et al., 2002; X. Wang et al., 2002). A few molecules expressed on oligodendrocytes have been shown previously to be upregulated after CNS lesions. This is the case for MBP (Bartholdi and Schwab, 1998), PLP (Frei et al., 2000), or versican (Asher et al., 2002), and only the latter is inhibitory for axonal growth. This transient upregulation of Sema4D expression could have just reflected the process of remyelination that occurs after the lesion. This is unlikely, however, because Sema4D upregulation is observed only during the first week that follows the injury, whereas oligodendrocyte proliferation lasts for at least 3-4 weeks (McTigue et al., 2001).

Our results could help developing therapeutic strategies to stimulate axonal regeneration. The three myelin inhibitors Omgp, Nogo, and MAG share the same receptor, NgR, the coreceptor $\mathrm{p} 75$, and probably signaling pathways (Domeniconi et al., 2002; Wang et al., 2002a,b). In the case of MAG, cAMP concentration is sufficient to convert its repulsive activity into an attraction (Song and Poo, 2001; Cai et al., 2002). cAMP can also decrease the inhibitory activity of myelin extracts in vitro (Cai et al., 1999) and even stimulate the axonal regeneration in vivo when injected into sensory ganglia (Neumann et al., 2002; Qiu et al., 2002). The presence of Sema4D on myelin suggests that it might also be important to stimulate the cGMP pathway because it seems to be involved in switching semaphorin response from attraction to repulsion (Song and Poo, 2001).

In conclusion, our results suggest that Sema4D plays important roles in the postnatal CNS and could participate in the inhibition of axonal regeneration; however, the exact mechanism of Sema4D inhibition is unclear and will require further studies. To ensure a better understanding of Sema4D function in the postnatal CNS, it will also be important to characterize the receptor mediating its inhibitory activity. Sema $4 \mathrm{D}$ has two known receptors. Plexin B1 is a high-affinity receptor for Sema4D (Tamagnone et al., 1999) that is widely expressed in fetal and adult tissue (Maestrini et al., 1996; Swiercz et al., 2002). The second receptor, CD72, with a lower affinity for Sema4D, is a transmembrane protein belonging to the C-type lectin family (Kumanogoh and Kikutani, 2001). We found that in the CNS plexin B1 is present at high levels in proliferating cells in the ventricular and subven- 


\section{A}

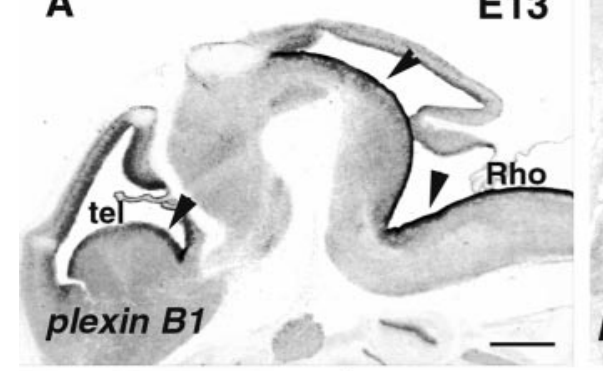

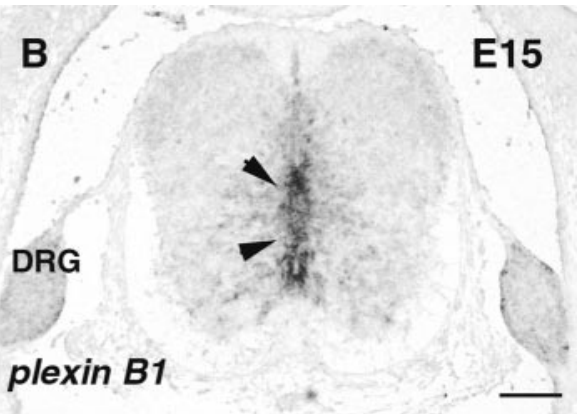

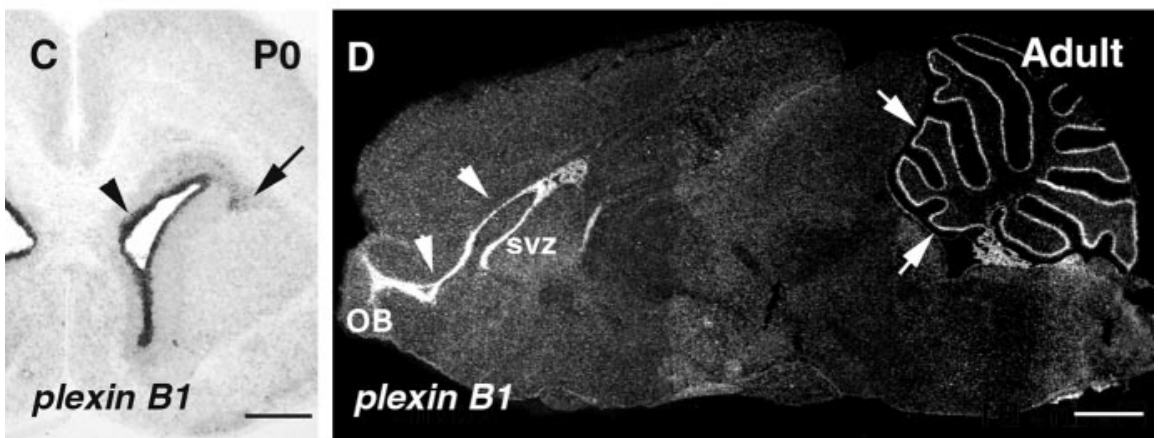

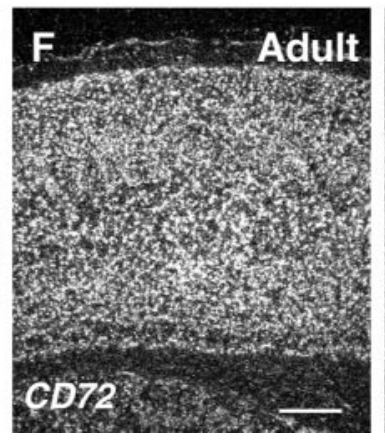

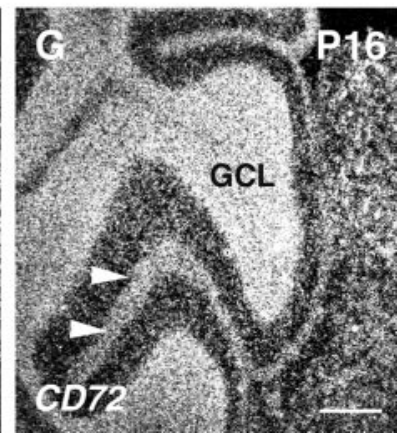

Figure 7. Expression of Sema4D receptors in the CNS. Coronal sections were hybridized with digoxigenin-labeled riboprobe $(A-C)$ or with ${ }^{35}$ S-labeled riboprobes $(D-G)$ for plexin $B 1(A-D)$ and $C D 72(E-G)$. $A$, At E13, plexin B1 mRNA is detected in the ventricular zone (arrowheads) from the rhombencephalon (Rho) to the telencephalon (tel). $B$, Coronal section at the level of the spinal cord of an $\mathrm{E} 15$ embryo. Plexin B1 transcripts are found in the ventricular zone lining the central canal (arrowheads). C, At P0, plexin $B 1$ is still expressed in the telencephalon and in the ventricular zone (arrowhead) but also in cells leaving the subventricular zone (arrow). $D$, In adult mouse, plexin B1 is detected exclusively in the subventricular zone (svz) and rostral migratory stream (arrowheads) to the olfactory bulb (OB). Purkinje cells (arrows) in the cerebellum also express plexin B1 mRNA. E, F, Coronal sections of adult mouse brain hybridized with CD72 riboprobe. CD72 mRNA is strongly and homogeneously expressed in all neurons, with the highest levels in the hippocampus (hi) and neocortex (Cx). F, High magnification of CD72 expression in the neocortex. G, Sagittal section through the cerebellum of a P16 mouse hybridized with CD72 riboprobe. CD72 is highly expressed in the granule cell layer (GCL) and in the external granule cell layer (arrowheads). Scale bars: $A, 300 \mu \mathrm{m} ; B, 1000 \mu \mathrm{m} ; C, 500 \mu \mathrm{m} ; D$, $1600 \mu \mathrm{m} ; E, 1000 \mu \mathrm{m} ; F, 300 \mu \mathrm{m} ; G, 200 \mu \mathrm{m}$.

tricular zones from early embryonic stages to adult but is not expressed by postnatal neurons, except cerebellar Purkinje cells. Thus, plexin B1 is unlikely to mediate Sema4D inhibitory activity. In contrast, CD72 mRNA was not detected in embryonic CNS but is strongly expressed in most, if not all, adult neurons. This suggests that CD72 could mediate Sema4D function in the CNS as in the immune system; however, additional receptors could also exist. Sema4A has recently been shown to act through Tim-2, a member of the family of $\mathrm{T}$ cell immunoglobulin domain and mucin domain proteins (Kumanogoh et al., 2002a).

Last, it will be important to determine whether axonal regeneration is improved in Sema4D mutants; however, this is unlikely considering the absence of major improvement of axonal regeneration in the CNS of MAG knock-outs (Bartsch et al., 1995) or Nogo knock-outs [see references in Woolf (2003)]. Overall, these results also reinforce the hypothesis for a role of axon guidance molecules in the inhibition of axonal regeneration (Ellezam et al., 2001; Manitt et al., 2001).

\section{References}

Asher RA, Morgenstern DA, Shearer MC, Adcock KH, Pesheva P, Fawcett JW (2002) Versican is upregulated in CNS injury and is a product of oligodendrocyte lineage cells. J Neurosci 22:2225-2236.

Bartholdi D, Schwab ME (1998) Oligodendroglial reaction following spinal cord injury in rat: transient upregulation of MBP mRNA. Glia 23:278-284.

Bartsch U, Bandtlow CE, Schnell L, Bartsch S, Spillmann AA, Rubin BP, Hillenbrand R, Montag D, Schwab ME, Schachner M (1995) Lack of evidence that myelin-associated glycoprotein is a major inhibitor of axonal regeneration in the CNS. Neuron 15:1375-1381.

Bottenstein J, Hayashi I, Hutchings S, Masui H, Mather J, McClure DB, Ohasa S, Rizzino A, Sato G, Serrero G, Wolfe R, Wu R (1979) The growth of cells in serum-free hormonesupplemented media. Methods Enzymol 58:94-109.

Bradbury EJ, Moon LD, Popat RJ, King VR, Bennett GS, Patel PN, Fawcett JW, McMahon SB (2002) Chondroitinase ABC promotes functional recovery after spinal cord injury. Nature 16:636-640.

Bray GM, Villegas-Perez MP, Vidal-Sanz M, Aguayo AJ (1987) The use of peripheral nerve grafts to enhance neuronal survival, promote growth and permit terminal reconnections in the central nervous system of adult rats. J Exp Biol 132:5-19.

Brehm U, Piddlesden SJ, Gardinier MV, Linington C (1999) Epitope specificity of demyelinating monoclonal autoantibodies directed against the human myelin oligodendrocyte glycoprotein (MOG). J Neuroimmunol 97:9-15.

Cai D, Shen Y, De Bellard ME, Tang S, Filbin ME (1999) Prior exposure to neurotrophins blocks inhibition of axonal regeneration by MAG and myelin via a cAMP-dependent mechanism. Neuron 22:89-101.

Cai D, Deng K, Mellado W, Lee J, Ratan RR, Filbin MT (2002) Arginase I and polyamines act downstream from cyclic AMP in overcoming inhibition of axonal growth MAG and myelin in vitro. Neuron 35:711-719.

Caroni P, Schwab ME (1988a) Antibody against myelin-associated inhibitor of neurite growth neutralizes nonpermissive substrate properties of CNS white matter. Neuron 1:85-96.

Caroni P, Schwab ME (1988b) Two membrane protein fractions from rat central myelin with inhibitory properties for neurite outgrowth and fibroblast spreading. J Cell Biol 106:1281-1288.

Charles P, Hernandez MP, Stankoff B, Aigrot MS, Colin C, Rougon G, Zalc B, Lubetzki C (2000) Negative regulation of central nervous system myelination by polysialylated-neural cell adhesion molecule. Proc Natl Acad Sci USA 97:7585-7590.

Chen MS, Huber AB, van der Haar ME, Frank M, Schnell L, Spillman AA, Christ F, Schwab ME (2000) Nogo-A is a myelin-associated neurite outgrowth inhibitor and an antigen for monoclonal IN-1. Nature 403:434-439.

Cohen RI, Rottkamp DM, Maric D, Barker JL, Hudson LD (2003) A role for semaphorins and neuropilins in oligodendrocyte guidance. J Neurochem $85: 1262-1278$.

Delaire S, Elhabazi A, Bensussan A, Boumsell L (1998) CD100 is a leukocyte semaphorin. Cell Mol Life Sci 54:1265-1276. 
Demerens C, Stankoff B, Allinquant B, Anglade P, Couraud F, Zalc B, Lubetzki C (1996) Electrical activity is necessary for central nervous system myelination. Proc Natl Acad Sci USA 93:9887-9892.

De Winter F, Oudega M, Lankhorst AJ, Hamers FP, Blits B, Ruitenberg MJ, Pasterkamp RJ, Gispen WH, Verhaagen J (2002) Injury-induced class 3 sempahorin expression in the rat spinal cord. Exp Neurol 175:61-75.

Domeniconi M, Cao X, Spencer T, Sivasankaran R, Wang KC, Nikulina E, Kimura N, Cai H, Deng K, Gao Y, He Z, Filbin MT (2002) Myelinassociated glycoprotein interacts with the Nogo66 receptor to inhibit neurite outgrowth. Neuron 35:283-290.

Dusart I, Schwab ME (1994) Secondary cell death and the inflammatory reaction after dorsal hemisection of the rat spinal cord. Eur J Neurosci 6:712-724.

Ellezam B, Selles-Navarro I, Manitt C, Kennedy TE, McKerracher L (2001) Expression of netrin-1 and its receptors DCC and UNC-5H2 after axotomy and during regeneration of adult rat retinal ganglion cells. Exp Neurol 168:105-115.

Fawcett JW, Asher RA (1999) The glial scar and central nervous system repair. Brain Res Bull 49:377-391.

Fournier AE, GrandPre T, Strittmatter SM (2001) Identification of a receptor mediating Nogo-66 inhibition of axonal regeneration. Nature 409:341-346.

Frei E, Klusman I, Schnell L, Schwab ME (2000) Reactions of oligodendrocytes to spinal cord injury: cell survival and myelin repair. Exp Neurol 163:373-380.

Furuyama T, Inagaki S, Kosugi A, Noda S, Saitoh S, Ogata M, Iwahashi Y, Miyazaki N, Hamaoka T, Tohyama M (1996) Identification of a novel transmembrane semaphorin expressed on lymphocytes. J Biol Chem 271:33376-33381.

Gao WQ, Hatten ME (1994) Immortalizing oncogenes subvert the establishment of granule cell identity in developing cerebellum. Development 120:1059-1070.

Gavazzi I (2001) Semaphorin-neuropilin-1 interactions in plasticity and regeneration of adult neurons. Cell Tissue Res 305:275-284.

GrandPré T, Nakamura F, Vartanian T, Strittmatter SM (2000) Identification of the Nogo inhibitor of axon regeneration as a reticulon protein. Nature 403:439-444.

GrandPré T, Li S, Strittmatter SM (2002) Nogo-66 receptor antagonist peptide promotes axonal regeneration. Nature 417:547-551.

Hall KT, Boumsell L, Schultze JL, Boussiotis VA, Dorfman DM, Cardoso AA, Bensussan A, Nadler LM, Freeman GJ (1996) Human CD100, a novel leukocyte semaphorin that promotes B-cell aggregation and differentiation. Proc Natl Acad Sci USA 93:11780-11785.

Herold C, Bismuth G, Bensussan A, Boumsell L (1995) Activation signals are delivered through two distinct epitopes of CD100, a unique $150 \mathrm{kDa}$ human lymphocyte surface structure previously defined by BB18 mAb. Int Immunol 7:1-8.

Horner PJ, Gage FH (2000) Regenerating the damaged central nervous system. Nature 407:963-970.

Huang DW, McKerracher L, Braun PE, David S (1999) A therapeutic vaccine approach to stimulate axon regeneration in the adult mammalian spinal cord. Neuron 24:639-647.

Huber AB, Wienmann O, Brösamle C, Oertle T, Schwab ME (2002) Patterns of Nogo mRNA and protein expression in the developing and adult rat and after CNS lesions. J Neurosci 22:3553-3567.

Jones LL, Yamaguchi Y, Stallcup WB, Tuszynski MH (2002) NG2 is a major chondroitin sulfate proteoglycan produced after spinal cord injury and is expressed by macrophages and oligodendrocyte progenitors. J Neurosci 22:2792-2803.

Kumanogoh A, Kikutani H (2001) The CD100-CD72 interaction: a novel mechanism of immune regulation. Trends Immunol 22:670-676.

Kumanogoh A, Watanabe C, Lee I, Wang X, Shi W, Araki H, Hirata H, Iwahori K, Uchida J, Yasui T, Matsumoto M, Yoshida K, Yakura H, Pan C, Parnes JR, Kikutani H (2000) Identification of CD72 as a lymphocyte receptor for the class IV semaphorin CD100: a novel mechanism for regulating B cell signaling. Immunity 13:621-631.

Kumanogoh A, Marukawa S, Suzuki K, Takegahara N, Watanabe C, Ch'ng E, Ishida I, Fujimura H, Sakoda S, Yoshida K, Kikutani H (2002a) Class IV semaphorin Sema4A enhances T-cell activation and interacts with Tim-2. Nature 419:629-633.

Kumanogoh A, Suzuki K, Ch'ng E, Watanabe C, Marukawa S, Takegahara N, Ishida I, Sato T, Habu S, Yoshida K, Shi W, Kikutani H (2002b) Require- ment for the lymphocyte semaphorin, CD100, in the induction of antigen-specific T cells and the maturation of dendritic cells. J Immunol 169:1175-1181.

Lu QR, Yuk D, Alberta JA, Zhu Z, Pawlitzky I, Chan J, McMahon AP, Stiles CD, Rowitch DH (2000) Sonic hedgehog-regulated oligodendrocyte lineage genes encoding bHLH proteins in the mammalian central nervous system. Neuron 25:317-329.

Lubetzki C, Demerens C, Anglade P, Villarroya H, Frankfurter A, Lee VM, Zalc B (1993) Even in culture, oligodendrocytes myelinate solely axons. Proc Natl Acad Sci USA 90:6820-6824.

Maestrini E, Tamagnone L, Longati P, Cremona O, Gulisano M, Bione S, Tamanini F, Neel BG, Toniolo D, Comoglio PM (1996) A family of transmembrane proteins with homology to the MET-hepatocyte growth factor receptor. Proc Natl Acad Sci USA 93:674-678.

Manitt C, Colicos MA, Thompson KM, Rousselle E, Peterson AC, Kennedy TE (2001) Widespread expression of netrin-1 by neurons and oligodendrocytes in the adult mammalian spinal cord. J Neurosci 21:3911-3922.

McKerracher L, David S, Jackson DL, Kottis V, Dunn RJ, Braun PE (1994) Identification of myelin-associated glycoprotein as a major myelinderived inhibitor of neurite growth. Neuron 13:805-811.

McTigue DM, Wei P, Stokes BT (2001) Proliferation of NG2-positive cells and altered oligodendrocyte numbers in the contused rat spinal cord. J Neurosci 21:3392-3400.

Moon LD, Asher RA, Rhodes KE, Fawcett JW (2001) Regeneration of CNS axons back to their target following treatment of adult rat brain with chondroitinase ABC. Nat Neurosci 4:465-466.

Mukhopadhyay G, Doherty P, Walsh FS, Crocker PR, Filbin MT (1994) A novel role for myelin-associated glycoprotein as an inhibitor of axonal regeneration. Neuron 13:757-767.

Neumann S, Bradke F, Tessier-Lavigne M, Basbaum AI (2002) Regeneration of sensory axons within the injured spinal cord induced by intraganglionic cAMP elevation. Neuron 34:885-893.

Nguyen-Ba-Charvet KT, Brose K, Marillat V, Sotelo C, Tessier-Lavigne M, Chedotal A (2001) Sensory axon response to substrate-bound Slit2 is modulated by laminin and cyclic GMP. Mol Cell Neurosci 17:1048-1058.

Norton WT, Poduslo SE (1973) Myelination in rat brain: method of myelin isolation. J Neurochem 21:749-757.

Olivier C, Cobos I, Perez Villegas EM, Spassky N, Zalc B, Martinez S, Thomas JL (2001) Monofocal origin of telencephalic oligodendrocytes in the anterior entopeduncular area of the chick embryo. Development 128:1757-1769.

Pasterkamp RJ, Verhaagen J (2001) Emerging roles for semaphorins in neural regeneration. Brain Res Brain Res Rev 35:36-54.

Pasterkamp RJ, De Winter F, Holtmaat AJ, Verhaagen J (1998a) Evidence for a role of the chemorepellent semaphorin III and its receptor neuropilin-1 in the regeneration of primary olfactory axons. J Neurosci 18:9962-9976.

Pasterkamp RJ, Giger RJ, Verhaagen J (1998b) Regulation of semaphorin III/collapsin-1 gene expression during peripheral nerve regeneration. Exp Neurol 153:313-327.

Pasterkamp RJ, Giger RJ, Ruitenberg MJ, Holtmaat AJGD, DeWit J, DeWinter F, Verhaagen J (1999) Expression of the gene encoding the chemorepellent semaphorin III is induced in the fibroblast component of neural scar tissue formed following injuries of adult but not neonatal CNS. Mol Cell Neurosci 13:143-166.

Perez Villegas EM, Olivier C, Spassky N, Poncet C, Cochard P, Zalc B, Thomas JL, Martinez S (1999) Early specification of oligodendrocytes in the chick embryonic brain. Dev Biol 216:98-113.

Perrot V, Vazquez-Prado J, JS Gutkind (2002) PlexinB regulates Rho through the guanine nucleotide exchange factors leukemia-associated Rho GEF (LARG) and PDZ-RhoGEF. J Biol Chem 277:43115-43120.

Pringle NP, Richardson WD (1993) A singularity of PDGF alpha-receptor expression in the dorsoventral axis of the neural tube may define the origin of the oligodendrocyte lineage. Development 117:525-533.

Prinjha R, Moore SE, Vinson M, Blake S, Morrow R, Christie G, Michalovich D, Simmons DL, Walsh FS (2000) Inhibitors of neurite outgrowth in humans. Nature 403:383-384.

Püschel AW, Adams RH, Betz H (1996) The sensory innervation of the mouse spinal cord may be patterned by differential expression of and differential responsiveness to semaphorins. Mol Cell Neurosci 7:419-431.

Qiu J, Cai D, Dai H, McAtee M, Hoffman PN, Bregman BS, Filbin MT (2002) 
Spinal axon regeneration induced by elevation of cAMP. Neuron 34:895-903.

Raper JA (2000) Semaphorins and their receptors in vertebrates and invertebrates. Curr Opin Neurobiol 10:88-94.

Ricard D, Rogemond V, Charrier E, Aguera M, Bagnard D, Belin MF, Thomasset N, Honnorat J (2001) Isolation and expression pattern of human Unc-33-like phosphoprotein 6/collapsin response mediator protein 5 (Ulip6/CRMP5): coexistence with Ulip2/CRMP2 in Sema3a-sensitive oligodendrocytes. J Neurosci 21:7203-7214.

Schwab ME, Bartholdi D (1996) Degeneration and regeneration of axons in the lesioned spinal cord. Physiol Rev 76:319-370.

Schwab ME, Caroni P (1988) Oligodendrocytes and CNS myelin are nonpermissive substrates for neurite growth and fibroblast spreading in vitro. J Neurosci 8:2381-2393.

Shi W, Kumanogoh A, Watanabe C, Uchida J, Wang X, Yasui T, Yukawa K, Ikawa M, Okabe M, Parnes JR, Yoshida K, Kikutani H (2000) The class IV semaphorin CD100 plays nonredundant roles in the immune system: defective $\mathrm{B}$ and $\mathrm{T}$ cells activation in CD100-deficient mice. Immunity 13:633-642.

Skaliora I, Singer W, Betz H, Puschel AW (1998) Differential patterns of semaphorin expression in the developing rat brain. Eur J Neurosci 10:1215-1229.

Song H, Poo M (2001) The cell biology of neuronal navigation. Nat Cell Biol 3:81-88.

Spassky N, Goujet-Zalc C, Parmantier E, Olivier C, Martinez S, Ivanova A, Ikenaka K, Macklin W, Cerruti I, Zalc B, Thomas JL (1998) Multiple restricted origin of oligodendrocytes. J Neurosci 18:8331-8343.

Spassky N, Olivier C, Cobos I, LeBras B, Goujet-Zalc C, Martinez S, Zalc B, Thomas JL (2001) The early steps of oligodendrogenesis: insights from the study of the plp lineage in the brain of chicks and rodents. Dev Neurosci 23:318-326.

Spassky N, de Castro F, Le Bras B, Heydon K, Queraud-LeSaux F, BlochGallego E, Chédotal A, Zalc B, Thomas JL (2002) Directional guidance of oligodendroglial migration by class 3 semaphorins and netrin-1. J Neurosci 22:5992-6004.

Streit WJ, Kreutzberg GW (1987) Lectin binding by resting and reactive microglia. J Neurocytol 16:249-260.

Sugimoto Y, Taniguchi M, Yagi T, Akagi Y, Nojyo Y, Tamamaki N (2001) Guidance of glial precursor cell migration by secreted cues in the developing optic nerve. Development 128:3321-3330.

Swiercz J, Kuner R, Behrens J, Offermans S (2002) Plexin B1 directly inter- acts with the PDZ-RhoGEF/LARG to regulate RhoA and growth cone morphology. Neuron 35:51-63.

Tamagnone L, Artigiani S, Chen H, He Z, Ming GL, Song HJ, Chédotal A, Winberg ML, Goodman CS, Poo MM, Tessier-Lavigne M, Comoglio PM (1999) Plexins are a large family of receptors for transmembrane, secreted, and GPI-anchored semaphorins in vertebrates. Cell 99:71-80.

Timsit SG, Bally-Cuif L, Colman DR, Zalc B (1992) DM-20 mRNA is expressed during the embryonic development of the nervous system of the mouse. J Neurochem 58:1172-1175.

Timsit S, Martinez S, Allinquant B, Peyron F, Puelles L, Zalc B (1995) Oligodendrocytes originate in a restricted zone of the embryonic ventral neural tube defined by DM-20 mRNA expression. J Neurosci 15:1012-1024.

Walter J, Kern-Veits B, Huf J, Stolze B, Bonhoeffer F (1987) Recognition of position-specific properties of tectal cell membranes by retinal axons in vitro. Development 101:685-696.

Wang KC, Koprivica V, Kim JA, Sivasankaran R, Guo Y, Neve RL, He Z (2002a) Oligodendrocyte-myelin glycoprotein is a nogo receptor ligand that inhibits neurite outgrowth. Nature 417:941-944.

Wang KC, Kim JA, Sivasankaran R, Segal R, He Z (2002b) P75 interacts with the Nogo receptor as a co-receptor for Nogo, MAG and OMgp. Nature 420:74-78.

Wang X, Chun SJ, Treloar H, Vartanian T, Greer CA, Strittmatter SM (2002) Localization of Nogo-A and Nogo-66 receptor proteins at sites of axonmyelin and synaptic contact. J Neurosci 22:5505-5515.

Williams-Hogarth LC, Puche AC, Torrey C, Cai X, Song I, Kolodkin AL, Shipley MT, Ronnett GV (2000) Expression of semaphorins in developing and regenerating olfactory epithelium. J Comp Neurol 423:565-578.

Woolf CJ (2003) No Nogo: now where to go? Neuron 38:153-156.

Wong K, Park H, Wu J, Rao Y (2002) Slit proteins: molecular guidance cues for cells ranging from neurons to leukocytes. Curr Opin Genet Dev 12:583-591.

Yamamura T, Konola JT, Wekerle H, Lees MB (1991) Monoclonal antibodies against myelin proteolipid protein: identification and characterization of two major determinants. J Neurochem 57:1671-1680.

Ying H, Nakayama E, Robinson WH, Parnes JR (1995) Structure of the mouse CD72 (Lyb-2) gene and its alternatively spliced transcripts. J Immunol 154:2743-2752.

Yu TW, Bargmann CI (2001) Dynamic regulation of axon guidance. Nat Neurosci 4:1169-1176. 